\title{
The adverse effects of bisphenol $A$ on male albino rats
}

\author{
Afaf H. Kamel*, Mona A. Foaud and Heba M. Moussa
}

\begin{abstract}
Background: Bisphenol A (BPA) is a monomer used in the production of a multitude of chemical products, including epoxy resins and polycarbonates. The purpose of this study was to consider the biochemical, histological, genetic, and molecular alterations induced by BPA in adult male albino rats. They were orally subjected to BPA (20 and $100 \mathrm{mg} / \mathrm{kg}$ body weight) mixed in olive oil once a day for 30 days. At the end of the experiment, liver, testis, serum, and bone marrow were collected.

Result: A significant increase in the level of malondialdehyde (MDA), with a significant decline in the content of superoxide dismutase (SOD) and reduced glutathione (GSH) in rats' livers and testes after administration of both doses of BPA occurred. Also, there was a significant decrease in the testosterone activity in both treated groups. Histopathologic effects of bisphenol A on livers and testes of male rats showed that the treatment with both doses of BPA resulted in deleterious effects on livers and testes. The frequency of the micronucleus (MN) in polychromatic erythrocytes (PCEs) in bone marrow cells at both doses was significantly increased as compared to control group, while no changes were observed in polychromatic erythrocytes/normochromatic erythrocytes (PCEs/NCEs) ratio. Finally, BPA caused a suppressive effect on spermatogenesisassociated 7 (SPATA 7) gene in a dose-dependent manner.

Conclusion: Exposure of rats to both selective doses of BPA leads to many adverse effects on liver and testis tissues. Also, an increase in frequency of the micronucleus in bone marrow cells was shown and suppression in the expression of SPATA 7 gene.
\end{abstract}

Keywords: Bisphenol A, DNA damage, Hepatotoxicity, SPATA 7 gene, Oxidative stress

\section{Background}

Numerous pollutants harmfully affect development and physiology by interfering with normal endocrine functions (e.g., phthalates, alkylphenolic compounds, polychlorinated biphenyls and dibenzodioxins, organochlorine pesticides, and different metals) (Gray Jr et al., 2001). The disturbing news is that these "endocrine-disrupting chemicals" (EDCs) have become everywhere in the environment and are usually found in the tissues of humans and wildlife.

One of the environmental contaminants and a famous estrogenic endocrine disruptor is the bisphenol A (BPA) which is used in the creation of polycarbonate plastic (e.g., water bottles, baby bottles) and epoxy resins (e.g., inside coating in metallic food cans) and as a non-polymer preservative to other plastics (Chitra, Latchoumycandane, \& Mathur, 2002; Hernandez-Rodriguez et al., 2007).

\footnotetext{
* Correspondence: Afaf.hendawy@women.asu.edu.eg

Zoology Department, Faculty of Women, Ain Shams University, Cairo, Egypt
}

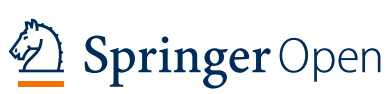

(c) The Author(s). 2018 Open Access This article is distributed under the terms of the Creative Commons Attribution 4.0 International License (http://creativecommons.org/licenses/by/4.0/), which permits unrestricted use, distribution, and reproduction in any medium, provided you give appropriate credit to the original author(s) and the source, provide a link to the Creative Commons license, and indicate if changes were made. (Chapin et al., 2008). However, recent evidence also point to that exposure to BPA may occur through dermal contact with thermal papers widely used in cash register receipts (Biedermann, Tschudin, \& Grob, 2010). Therefore, it becomes an included part of the food chain (Vandenberg et al., 2010; Huang et al., 2011).

BPA has been detected in the urine and serum samples from reference population of 394 adults in the USA (Calafat et al., 2005). Accumulation of BPA in early fetuses and significant exposure during the prenatal period (Ikezuki, Tsutsumi, Takai, Kamei, \& Taketani, 2002) must be considered in evaluating the possibility of human exposure to endocrine-disrupting chemicals. Also, it is recognized in placental tissue and in the milk of lactating mothers (Schonfelder et al., 2002). All these studies incorporated that indeed, human beings are getting exposed to BPA. This has raised a great fear regarding human health and environmental exposure to BPA. 
The harmful effects of BPA are largely associated to its estrogenic activity (Kurosawa et al., 2002). The exposure of animal to BPA elucidates multiple effects on the male and female reproductive system in various animal models. Different doses of BPA (2 $\mu \mathrm{g}$ to $200 \mathrm{mg} / \mathrm{kg}$ ) caused inhibition in spermatogenesis and seminiferous tubule in male chicks (Furuya, Adachi, Kuwahara, Ogawa, \& Tsukamoto, 2006).

BPA caused a decrease in sperm count and motility and also affected sperm morphology of adult male rats (Sakaue et al., 2001). BPA has been associated with declined semen quality and increased sperm DNA damage; this also supports the toxicity of BPA on germ cell (Meeker et al., 2010).

Low doses of BPA show oxidative stress in livers of male rats (Bindhumol, Chitra, \& Mathur, 2003). The liver is the primary organ responsible for BPA metabolism in humans and animals.

On activation, Kupffer cells (KCs) located in the lumen of the liver sinusoids release different cytokines and play a vital role in the pathogenesis of various liver diseases (Wu, Chuang, Yang, \& Lin, 2010). KCs have been concerned as the source of the inflammatory response, because they are well-known to generate proinflammatory cytokines, such as interleukin (IL)-1beta and IL-6 when activated (Kopf, Bachmann, \& Marsland, 2010).

Hussein and Eid (2013) demonstrated that BPA exposure for male Swiss albino mice increased hepatic oxidative stress and proinflammatory cytokines and decreased the antioxidant catalase enzyme activity.

The genetic toxicity of BPA in somatic cells has been reported in vitro using micronucleus test in hamster V79 cells (Pfeiffer, Rosenberg, Deuschel, \& Metzler, 1997), human MCL-5 cells (Parry et al., 2002), human lymphoblastoid cell lines, and Chinese hamster V79 cell lines (Johnson \& Parry, 2008).

BPA is a potent meiotic aneugen, specifically, in female mice. Short-term, low-dose exposure during the final stages of oocyte growth is sufficient to elicit detectable meiotic effects (Hunt et al., 2003). BPA caused micronuclei formation in different organisms' organs like mussel gills (Barsiene, Syvokiene, \& Bjornstad, 2006) and fish erythrocytes (Bolognesi, Perrone, Roggieri, Pampanin, \& Sciutto, 2006). Additionally, some studies have indicated that BPA has the possibility to induce point mutation. Takahashi et al. (2001) suggested that treatment of human RSa cells with bisphenol $\mathrm{A}$ at concentrations ranging from $1 \times 10^{-7}$ to $1 \times 10^{-5} \mathrm{M}$ lead to increase of $\mathrm{K}$-ras codon 12 mutations. Also, Tsutsui et al. (2000) examined the transforming and genotoxic activities of four types of bisphenols (BP-2, BP-3, BP-4, BP-5) in Syrian hamster embryo (SHE) cells and compared them with BPA; the most aneuploidogenic activity of bisphenol was BPA due to its chemical structure.

Nakagawa and Tayama (2000) reported that BPA induced mitochondrial dysfunction, including a decrease in mitochondrial transmembrane potential and altered cellular oxidation-reduction in the isolated rat hepatocytes and in human HepG2 cell (Huc, Lemarie, Gueraud, \& Helies-Toussaint, 2012), suggesting that mitochondria are a board of BPA at organelle level. It is recognized that mitochondria play a vital role in apoptosis by releasing the intermembrane space proteins, such as cytochrome c (Cyt c), which is a key mediator of apoptosis for activation of caspase in the cytosol (Kroemer, Galluzzi, \& Brenner, 2007, Vaux, 2011). Recently, Xia, Jiang, Li, Wan, and Liu (2014) showed that BPA induces mitochondria-mediated apoptosis in hepatic cells.

The present study aims to investigate the hazardous effects on male albino Wistar rats after exposure to BPA (20 and $100 \mathrm{mg} / \mathrm{kg}$ body weight) for 30 days through biochemical assessment by measuring the content of "superoxide dismutase" (SOD), reduced glutathione (GSH), and malondialdehyde (MDA) in the liver and testis; also, serum testosterone level was determined. Moreover, histopathological examination of liver and testis tissues was studied, in addition to genotoxic analysis and the level of SPATA 7 gene expression level using RT-PCR.

\section{Methods}

\section{Animals and treatment}

Thirty male albino rats of Wister strain average body weight of 120-200 g were used in the present study. Animals were housed in the vivarium of the animal house of Medical Research of Bilharizia Center, Faculty of Medicine, Ain Shams University. They were kept under controlled environmental circumstances. Animals were allowed standard pellet diet and water ad libitum for the whole period of the experiment. The animals were left at least 1 week before the beginning of experiments for acclimatization to laboratory condition.

Bisphenol A (BPA) (2,2-di(4-hydroxyphenyl) propane) of $97 \%$ purity was purchased from Sigma chemical Co. and diluted with olive oil to obtain a final concentration of 20 and $100 \mathrm{mg} / \mathrm{kg}$ body weight (bw). The doses were selected according to Jayashree et al. (2013). The oral $\mathrm{LD}_{50}$ of BPA in rats was $3250 \mathrm{mg} / \mathrm{kg}$ body weight as described by MSDS (2004).

Animals were divided into three groups, each of ten animals as follows:

group I: control group (olive oil alone), group II: lowdose BPA (20 mg/kg bw), and group III: high-dose BPA (100 $\mathrm{mg} / \mathrm{kg} \mathrm{bw})$. All treatment were given to animals orally for a duration of 30 consecutive days. At the end of the experiment, rats were sacrificed $24 \mathrm{~h}$ following the last given dose. Blood samples were withdrawn and collected in glass tubes; serum was separated by centrifugation at $1800 \times g$ for $10 \mathrm{~min}$ and stored at $4{ }^{\circ} \mathrm{C}$ to determine serum testosterone. Livers and testes were rapidly dissected, washed with isotonic saline, and divided into two halves. 
One half of each organ was instantly homogenized to give $10 \%(w / v)$ homogenate in ice-cold medium containing $10 \mathrm{~m} \mathrm{~mol} / \mathrm{L}$ phosphate-buffered saline $\mathrm{pH}$ 7.4. The homogenate was centrifuged at $1800 \times \mathrm{g}$ for $10 \mathrm{~min}$ in cooling centrifuge at $4{ }^{\circ} \mathrm{C}$. The supernatant $(10 \%)$ was separated for biochemical analyses. The other half of each organ was fixed in formalin buffer for histopathological investigation.

\section{Measurement of biomarker of oxidative stress}

Malondialdehyde (MDA) content was determined in liver and testis by using TBARS assay kit purchased from Cell Biolabs, Inc. Co., according to the method described by Armstrong (1998).

\section{Assay of antioxidant enzymes}

The content of superoxide dismutase (SOD) in the liver and testis was estimated by using SOD assay kit purchased from Trevigen, Inc. Co. according to the method described by Lu and Finkel (2008). Reduced glutathione (GSH) in liver and testis was determined by using Total Glutathione (GSSG/GSH) Assay Kit purchased from Cell Biolabs, Inc. Co., according to the method described by Mytilineou (2002).

\section{Serum testosterone level}

Serum testosterone level was assayed by ELISA technique using testosterone assay kit purchased from Kamiya Biomedical Co., according to the manufacturer's instructions provided with testosterone assay kit.

\section{Histopathological investigations}

Tissues were fixed in $10 \%$ buffered formalin, processed for microtomy, and stained with hematoxylin and eosin, for histological study (Bancroft, Stevens, \& Turner, 1996).

\section{Micronucleus test (MNT)}

Bone marrow preparations were made after the end of experiment, and slides were prepared by employing the modified method of Rao, Rahiman, and Koranne (1983). The air-dried slides were fixed in methanol and stained with May-Grunwald-Giemsa. One thousand polychromatic erythrocytes (PCEs) were counted in each slide. In addition, PCEs/NCEs ratio was recorded per animal to evaluate bone marrow toxicity.

\section{Detection of spermatogenesis-associated 7 (SPATA 7) gene expression by reverse transcriptase polymerase chain reaction (RT-PCR) analysis}

Total RNA was extracted from testis homogenate using $\mathrm{S}$ $\mathrm{V}$ total RNA isolation system (Promega, Madison, W I, USA), according to the manufacturer's information. The RNA concentration was determined with the NanoDrop ND-1000 spectrophotometer, and RNA purity was determined by means of the absorbance ratio at 260/280 $\mathrm{nm}$.
The integrity of RNA was assessed by electrophoresis on $2 \%$ agarose gels. One microgram of RNA was used in the subsequent cDNA synthesis reaction, which was performed using the Reverse Transcription PCR kit (stratagene, USA). Total RNA was incubated at $70{ }^{\circ} \mathrm{C}$ for $10 \mathrm{~min}$ to avoid secondary structures. Then, RNA was supplemented with $\mathrm{MgCl}_{2}$ (25 mM), RTase buffer (10×), dNTP mix (10 mM), oligo $d(t)$ primers, RNase inhibitor (20 U), and AMV reverse transcriptase $(20 \mathrm{U} / \mu \mathrm{l})$. After that, the mixture was incubated at $42{ }^{\circ} \mathrm{C}$ for $1 \mathrm{~h}$.

\section{Quantitative real-time PCR}

qPCR was performed with an ABI PRISM 7500 fast sequence detection system (Applied Biosystems, Carlsbad, California) and universal cycling conditions (min $95{ }^{\circ} \mathrm{C}$, 40 - cycles of $15 \mathrm{~s}$ at $95{ }^{\circ} \mathrm{C}$ and $60 \mathrm{~s}$ at $60{ }^{\circ} \mathrm{C}$ ). Each $10 \mu$ reaction contained $5 \mu$ l SYBR Green Master Mix, $0.3 \mu$ l gene-specific forward and reverse primer $(10 \mu \mathrm{M})$, $2.5 \mu \mathrm{lDNA}$, and $1.9 \mu \mathrm{l}$ water nuclease free. The sequence of primer used for RT-PCR was forward: 5 ' -GCAGGACA GAACGACTCAGGCGGG-3' and reverse: 5' -TCCT GCGGGAACTGCTGGTGGTGTAG-3' as reported by Livak and Schmittgen (2001). Expression of housekeeping gene GAPDH served as the control.

\section{Statistical analysis}

Our data were analyzed with one-way analysis of variance (ANOVA) using the statistical package for the social science (SPSS) program, version 11 followed by least significant difference (LSD) to compare significance between groups (Armitage \& Berry, 1987). Difference was significant when $P$ value was $<0.001$.

\section{Results}

Level of MDA, SOD, and GSH in the liver

The results of MDA,SOD, and glutathione (GSH) recorded that MDA level was significantly increased $(P<0.05)$ in the liver tissue after oral administration of both doses (20 and $100 \mathrm{mg} / \mathrm{kg} \mathrm{bw}$ ) of BPA for 30 days showing 20.50 and $52.30 \mathrm{nmol} / \mathrm{g}$ tissue, respectively, when compared to the corresponding control group. SOD and GSH content exhibited significant decrease $(P<0.05)$ in their levels of the liver tissue after oral administration of both two doses of BPA for 30 days as compared with the corresponding control group 4.33 and $1.25 \mathrm{U} / \mathrm{g}$ tissue, respectively, for SOD and 2.04 and $0.90 \mu \mathrm{mol} / \mathrm{g}$ tissue, respectively, for GSH as shown in Table 1.

\section{Level of MDA, SOD, and GSH in testis}

The effect of BPA on the oxidative stress biomarkers is presented in Table 2. The data indicated that there was a significant increase $(P<0.05)$ of MDA content in testis tissue of animal group treated with both low and high doses of BPA for 30 days which recorded 7.60 and $20.13 \mathrm{nmol} / \mathrm{g}$ 
Table 1 The effect of BPA on the liver MDA, SOD, and GSH level

\begin{tabular}{llll}
\hline Group & Parameter & & \\
\cline { 2 - 4 } & MDA & SOD & GSH \\
\hline Control & $7.02 \pm 1.24$ & $10.16 \pm 0.92$ & $4.53 \pm 0.47$ \\
Low dose & $20.50 \pm 2.44^{*}$ & $4.33 \pm 0.48^{*}$ & $2.04 \pm 0.21^{*}$ \\
High dose & $52.30 \pm 5.01^{*}$ & $1.25 \pm 0.15^{*}$ & $0.90 \pm 0.09^{*}$ \\
\hline
\end{tabular}

Data are represented as mean \pm SD, for 10 rats/group

${ }^{*} P<0.001$ significant from control group

tissue, respectively, when compared to control group. However, a significant decline $(P<0.05)$ in the content of SOD and GSH in the testis tissue are shown after oral administration of BPA at low and high doses recording 1.12 and $0.41 \mathrm{U} / \mathrm{g}$ tissue for SOD and 0.82 and $0.12 \mu \mathrm{mol} / \mathrm{g}$ tissue for GSH, respectively.

The effect of BPA on the level of serum testosterone Table 3 shows that oral administration of BPA at both low and high doses for 30 days caused a significant decrease $(P<0.05)$ in the testosterone activity recording 1.70 and $0.72 \mathrm{ng} / \mathrm{ml}$, respectively, as compared with the control group.

\section{Histopathological analysis}

In comparison with control (Fig. 1a), histological examination of liver sections from the low-dose BPA treated rat revealed early degenerative changes in parenchymal cells and mild sinusoidal congestion. Signs of multifocal vacuolar degeneration and lymphoid aggregates were apparent (Fig. 1b). However, hepatic histopathological sections of the rat treated with high doses of BPA have increased inflammatory cells, distended blood sinusoids, and vacuolized swollen hepatocytes, with pyknotic nuclei (Fig. 1c, d). In addition, increase in Kupffer cells (Fig. 1e), eosinophilic material, infiltration of inflammatory cells, and distorted hepatic architecture was evident (Fig. 1f). In addition to pyknotic nuclei, Kupffer cells, and widening of the blood sinusoids, hyaline material was present in between hepatocytes (Fig. 1g).

Histopathological sections of testes from rat group administrated BPA at low dose exhibited marked irregular outline of seminiferous tubules that appeared damaged including detached degenerative primary spermatogonia from the wall of seminiferous tubules and congestion of interstitial blood (Fig. 2b, c) as compared to normal control (Fig. 2a). On the

Table 2 The effect of BPA on testis MDA, SOD, and GSH level

\begin{tabular}{llll}
\hline Group & \multicolumn{3}{l}{ Parameter } \\
\cline { 2 - 4 } & MDA & SOD & GSH \\
\hline Control & $2.17 \pm 0.34$ & $3.60 \pm 0.41$ & $1.53 \pm 0.12$ \\
Low dose & $7.60 \pm 1.20^{*}$ & $1.12 \pm 0.06^{*}$ & $0.82 \pm 0.09^{*}$ \\
High dose & $20.13 \pm 1.88^{*}$ & $0.41 \pm 0.04^{*}$ & $0.12 \pm 0.01^{*}$ \\
\hline
\end{tabular}

Data are represented as mean $\pm S D$, for 10 rats/group

${ }^{*} P<0.001$ significant from control group
Table 3 The effect of BPA on serum testosterone level

\begin{tabular}{llll}
\hline Parameter & Group & \\
\cline { 2 - 4 } & Control & Low dose & High dose \\
\hline Testosterone & $3.60 \pm 0.41$ & $1.70 \pm 0.14^{*}$ & $0.72 \pm 0.09^{*}$
\end{tabular}

Data are represented as mean $\pm S D$, for 10 rats/group

${ }^{*} P<0.001$ significantly from control group

other hand, in the experimental group receiving high dose, the rats' testes showed marked distoration of the seminiferous tubules with thin and folded basal lamina, destruction of walls of seminiferous tubules, and separation of germinal epithelia (Fig. 2d). Edematous fluid between seminiferous tubules and destruction in the wall of some seminiferous tubules showing arrest of spermatogenic layers were also observed (Fig. 2e).

\section{Micronucleus test (MNT)}

A significant increase in number of MN-PCEs was illustrated in rats treated with BPA at low dose $(20 \mathrm{mg} / \mathrm{kg})$ and high dose $(100 \mathrm{mg} / \mathrm{kg})$ as compared to control as shown in Table 4. The cytotoxic effect of BPA on bone marrow cells was experienced by assessing polychromatic erythrocytes/normochromatic erythrocytes (PCEs/NCEs) ratio. As far as PCEs/NCEs ratio is disturbed, it remained well within the acceptable range and the ratio was near to the control.

\section{Expression of spermatogenesis-associated 7 gene}

BPA caused a significant decrease in SPATA 7 gene expression with administration of low dose $20 \mathrm{mg} / \mathrm{kg}$ body weight $(0.78 \pm 0.009)$, while high doses $(100 \mathrm{mg} / \mathrm{kg}$ body weight) exhibited very highly significant decrease $(0.485 \pm 0.0098)$ when compared with control group (1.01 \pm 0.03$)$ (Fig. 3).

\section{Discussion}

BPA has been confirmed in both in vivo and in vitro experiments to act as an endocrine-disrupting chemical liberated into the environment (Richter et al., 2007). In view of the present results, rats administered BPA displayed a significant increase of MDA content in liver and testis tissues in all treated groups when compared with control group. These results are in agreement with the finding of Korkmaz, Ahbab, Kolankaya, and Barlas (2010) who reported an increase in thiobarbituric acid reactive substance (TBARS) level in the liver of rats exposed to BPA. Nandi, Patra, and Swarup (2005) showed that the increase in TBARS level and decreased GSH concentration indicates an increased generation of reactive oxygen species (ROS) that lead to lipid peroxidation in the liver.

These clarifications are in accordance with the report of Mourad and Khadrawy (2012) who demonstrated significant increase in lipid peroxidation levels in the liver and testis after daily oral administration of BPA. Also, Tiwari 


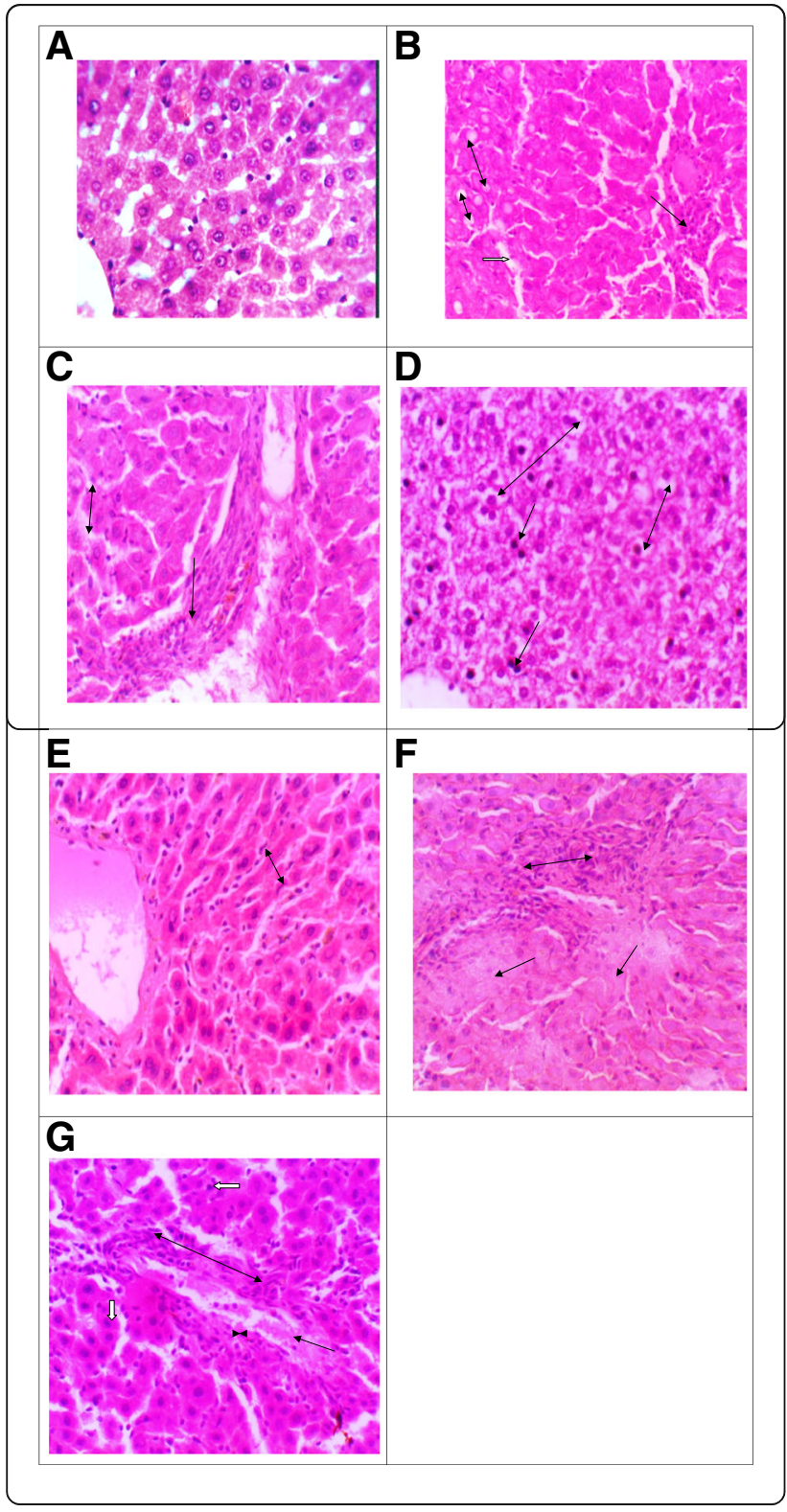

Fig. 1 a Photomicrograph of liver section from control rat showing normal hepatic architecture with cords of hepatocytes radiating from the central vein and separated by blood sinusoids (H\&E $\times 400$ ). b Photomicrograph of liver section from treated rat of low dose revealing vacuolar changes (arrow with two heads), inflammatory cells (black arrow), and distended sinusoidal space (white arrow) (H\&E ×400). c Photomicrograph of liver section from treated rat of high dose showing increased inflammatory infiltration (black arrow) and distended sinusoidal space (arrow with two heads) (H\&E $\times 400$ ). d Photomicrograph of liver section from treated rat of high dose showing pyknotic nuclei (black arrow) and swelled vacuolized hepatocyte (black arrow with two heads). e Photomicrograph of liver section from treated rat of high dose showing an increase in Kupffer cells (black arrow with two heads) (H\&E $\times 400)$. f Photomicrograph of liver section from treated rat of high dose showing eosinophilic material (black arrow), infiltration of inflammatory cells (black arrow with two heads), and distorted hepatic architecture $(H \& E \times 400)$. g Photomicrograph of liver section from treated rat of high dose showing distorted hepatic architecture, pyknotic nuclei (white arrow), hyaline material (black arrow), and inflammatory cells (black arrow with heads) (H\&E ×400)

et al. (2012) mentioned that BPA treatment caused a significant increase in the levels of lipid peroxidation. These effects reveal a state of oxidative stress in testicular tissue. It is obvious from the present data that both the high and low doses of BPA could induce oxidative stress in the testis. This may be due to the fact that the testicular membranes are rich in polyenoic fatty acids that are prone to undergo peroxidative decomposition (Rosenblum, Gavaler, \& Van Thiel, 1989).

The non-enzymatic levels of antioxidant GSH and enzymatic antioxidant (SOD) activity were measured to estimate the stability of ROS production in the liver. In the current study, the oral administration of BPA (low and high doses) revealed a significant decrease of SOD and GSH in liver and testis tissues of male rat treated groups as compared to control group. The decrease in GSH level with increased BPA concentration may be due to increased consumption of glutathione for the scavenging of ROS. These results are consistent with that of Hassan, Elobeid, Virk, Omer, and ElAmin (2012) who showed that BPA caused a significant decline in the levels of GSH, along with a decrease in the activity of SOD. In accordance with the present results, Wu, Xu, Shen, Qiu, and Yang (2011) showed a significant decrease in the levels of GSH and SOD in BPA group; this decrease indicated liver tissue damage. In rat liver, BPA declines the activity of the malespecific cytochrome P450 isoforms, testosterone $2 \alpha$ and $6 \beta$ hydroxylase (Hanioka, Jinno, Nishimura, \& Ando, 1998). The reduced cytochrome $\mathrm{P} 450$ has been shown to provoke ROS that impair sperm function (Griveau, Dumont, Renard, Callegari, \& Le Lannou, 1995).

Presently, BPA administration produces a significant decrease in serum level of testosterone when compared with control group. Similarly, serum testosterone level 


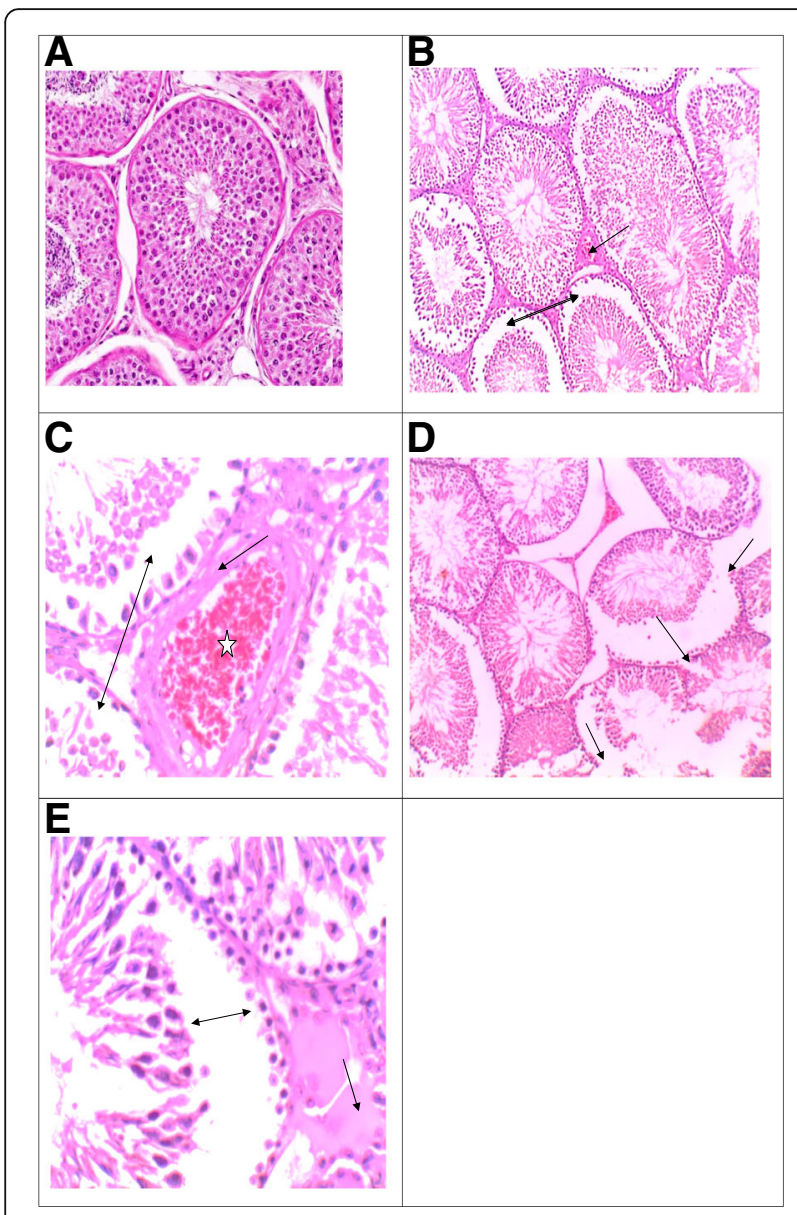

Fig. 2 a Photomicrograph of control testis showing normal testicular architecture with an orderly arrangement of differentiating spermatogenic and sertoli cells in the wall of these miniferous tubules and Leydig cells in the interstitial space (H\&E ×400). b Photomicrograph of testis section from treated rat of low dose showing separation of germinal epithelia of seminiferous tubules (black arrow with two heads) and congestion of interstitial spaces with blood (black arrow) (H\&E ×200). c Enlarged section of $\mathbf{b}$ showing detached degenerative primary spermatogonia from the wall of seminiferous tubules (black arrow with two heads), congested interstitial artery (star), and thickening of its wall (black arrow) (H\&E $\times 400)$. d Photomicrograph of testis section from treated rat of high dose showing separation and destruction of walls of seminiferous tubules (black arrow with two heads) (H\&E $\times 200)$. e Photomicrograph of testis section from treated rat of high dose showing pinkish edematous fluid between seminiferous tubules (black arrow) and arrest of spermatogenic layers of seminiferous tubules (black arrow with two heads) (H\&E $\times 400)$

was significantly decreased in BPA treated groups (Jayashree et al., 2013).

Also, Kawai et al. (2003) reported that serum testosterone levels decreased in male mice following fetal exposure to BPA. These results are in agreement with that of Nakamura et al. (2010) who stated that BPA decreased the expressions of steroidogenic acute regulatory (StAR) protein and steroidogenic enzymes like cholesterol side- chain cleaving enzyme P450scc (CYP11A1), P45017_, and 17_-HSD mRNA dose dependently. Therefore, the decreased expression of steroidogenic enzymes and StAR protein concerned in testosterone synthesis might be primarily related to the decreased testosterone levels as a result of BPA treatment.

In the current study, hepatic damage induced by BPA may be due to accumulation of BPA toxic metabolites and ability of the generation of ROS in the liver. Hepatic histopathological sections of the rats revealed vacuolar degeneration, necrosis, widening of blood sinusoids, vacuolization swelling in hepatocytes, and pyknosis in nuclei with increased number of Kupffer cells. These data are in harmony with Hassan et al. (2012), Hassan, Ismail, and Khudir (2013), and Eid, Eissa, and EL-Ghor (2015). Degenerative changes in hepatic cells were also noted by Boshra and Moustafa (2011), Roy, Kalita, and Mazumdar (2011), and Mourad and Khadrawy (2012).

Moreover, a study by Verma and Sangai (2009) showed that treatment with bisphenol A lead to cell and membrane damage of human erythrocytes which was due to oxidative stress. The degree of cellular infiltration and number of Kupffer cells is gradually increased with high levels of administration BPA. It was evidenced that hepatic macrophages and Kupffer cells are vital players in the propagation of acute liver injury. These cells attracted much attention recently in the context of chronic liver inflammation due to their dual pro- and antifibrotic qualities (Zimmermann \& Tacke, 2011).

An increase of pro-inflammatory cytokines disturbs the homeostasis of oxidants/anti-oxidants and also DNA repair enzymes, all of which illustrate the inflammatory processes related to BPA (Yongvanit, Pinlaor, \& Bartsch, 2012).

In the present study, the testes of rats exposed to BPA showed separation of germinal epithelia, obliteration in the wall of some seminiferous tubules, and eosinophilic material between seminiferous tubules, a finding that coincides with Hassan et al. (2013).

ROS are cytotoxic agents that cause significant oxidative damage by attacking biomolecules such as membrane lipids and DNA in cells (Kabuto, Hasuike, Minagawa, \& Shishibori, 2003). Antioxidants defuse ROS by acting as scavengers, helping to avoid cell and tissue damage that lead to cellular damage and disease (Halliwell, 1996).

Table 4 Micronucleated polychromatic erythrocyte (MN-PCEs) in the bone marrow of male rats exposed to BPA

\begin{tabular}{llll}
\hline Groups & Dose $(\mathrm{kg} / \mathrm{bw})$ & MN-PCEs $(\%)$ & PCEs/NCEs ratio \\
\hline 1 & Control (olive oil) & $0.97 \pm 1.36$ & $0.83 \pm 0.04$ \\
2 & $20 \mathrm{mg} / \mathrm{kg} \mathrm{BPA}$ & $3.036 \pm 2.16^{*}$ & $0.88 \pm 0.03$ \\
3 & $100 \mathrm{mg} / \mathrm{kg} \mathrm{BPA}$ & $10.15 \pm 5^{* *}$ & $0.80 \pm 0.07$ \\
\hline
\end{tabular}

$M N$-PCEs micronucleated polychromatic erythrocytes, $P C E s$ polychromatic erythrocytes, NCEs normochromatic erythrocytes

${ }^{* *} p<0.005,{ }^{*} p<0.001$ 


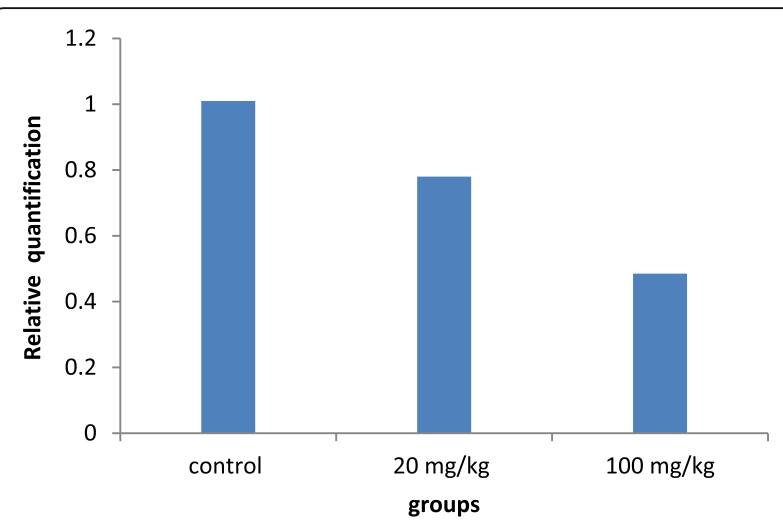

Fig. 3 Effect of bisphenol A on spermatogenesis-associated 7 (SPATA 7) expression in the testis of adult male albino rat

MNT has the capability to identify both clastogenic (structural) and aneugenic (numerical) chromosome alterations respectively (Fenech, 2000).

To validate the genotoxic effect of BPA, the MNT was used. In the present study, a significant increase in the frequency of $\mathrm{MN} /$ polychromatic erythrocytes in bone marrow cells of male rats exposed to BPA was recorded as compared to control group. These data are in accordance with Masuda et al. (2005), where they found that nitrosylated BPA could induce $\mathrm{MN}$ in the bone marrow cells of mice. One of the possibilities of the existence of micronuclei could be due to the aneugenic effects of BPA (Hunt et al., 2003; Quick, Parry, \& Parry, 2008). Also, BPA was evaluated for its ability to induce MN in cell types such as the human lymphoblastoid cell line MCL5 (Parry et al., 2002), human lymphoblastoid cell line AHH-1, and Chinese hamster V79 cells (Johnson \& Parry, 2008). In each case, BPA caused chromosome separation anomalies of non-disjunction and $\mathrm{MN}$, in a dosedependent manner. Pfeiffer, Rosenberg, Deuschel, and Metzler (1997) confirmed an aneuploidogenic possibility of BPA and four of its analogs in cultured Chinese hamster V79 cells.

Spermatogenesis is a complex process involving multigene interactions (Eddy, 2002; Vanderhyden, 2002), and the study of spermatogenesis may lead to illumination of the physiological and pathological processes of fertility (Nakanishi, 1995).

A significant suppressed effect on SPATA 7 gene in male rats after 30 days of oral administration of BPA was showed. Such results are matching with the previous data, made by Schonfelder et al. (2002) who reported that human exposure to BPA at its levels present in the environment has harmful effects. Blood BPA levels in a group of pregnant mothers and their fetuses ranged from $0.3-18.9$ and $0.2-9.2 \mathrm{ng} / \mathrm{ml}$, respectively, implying that human exposure to low BPA levels may exert adverse biological effects.

Akingbemi, Sottas, Koulova, Klinefelter, and Hardy (2004) demonstrated that exposure to environmentally relevant BPA levels has adverse effects on testicular function by decreasing luteinizing hormone and pituitary secretion and reducing Leydig cell steroidogenesis.

\section{Conclusions}

This study showed that exposure to the two doses of BPA (20 and $100 \mathrm{mg} / \mathrm{kg} \mathrm{bw}$ ) induces dysfunction in the physiological and histological structure of the liver and testis tissues. It also led to suppressor effect on SPATA 7 gene which is responsible for fertility in males. Finally, we recommended the limit of using products containing BPA.

\section{Abbreviations}

BPA: Bisphenol A; Cyt c: Cytochrome c; EDCs: Endocrine-disrupting chemicals; GAPDH: Glyceraldehyde 3-phosphate dehydrogenase; GSH: Reduced glutathione; KCs: Kupffer cells; LD 50 : Lethal dose 50; MDA: Malondialdehyde; MN: Micronucleus; MNT: Micronucleus test; NCEs: Normochromatic erythrocytes; PCEs: Polychromatic erythrocytes; ROS: Reactive oxygen species; RT-PCR: Reverse transcriptase polymerase chain reaction; SHE cells: Syrian hamster embryo cells; SOD: Superoxide dismutase; SPATA 7 gene: Spermatogenesis-associated 7; StAR: Steroidogenic acute regulatory; TBARS: Thiobarbituric acid reacting substances; $W /$ $v$ : Weight/volume; Xg: Times gravity

\section{Acknowledgements}

The authors thank assistant professor doctor Nashwa El-shinnawy from the Department of Zoology, Faculty of Women, Ain Shams University, Egypt, for her helpful comments on the manuscript.

\section{Funding}

There is no funding for this study. This study was conducted on personal expenses of authors.

\section{Availability of data and materials}

The authors agree for the availability of supporting data.

\section{Authors' contributions}

AK was responsible for planning the experiment. MF was responsible for the histopathological part. HM was responsible for the physiological part. All authors cooperated in writing the paper. All authors read and approved the final manuscript.

Ethical approval and consent to participate

Ethical approval was used in animal house of Medical Research of Bilharizia Center, Faculty of Medicine, Ain Shams University.

Consent for publication

Authors agree.

Competing interests

The authors declare that they have no competing interests.

\section{Publisher's Note}

Springer Nature remains neutral with regard to jurisdictional claims in published maps and institutional affiliations.

Received: 18 May 2017 Accepted: 5 January 2018

Published online: 29 January 2018

\section{References}

Akingbemi, B. T., Sottas, C. M., Koulova, A. I., Klinefelter, G. R., \& Hardy, M. P. (2004). Inhibition of testicular steroidogenesis by the xenoestrogen bisphenol a is associated with reduced pituitary luteinizing hormone secretion and decreased steroidogenic enzyme gene expression in rat Leydig cells. Endocrinology, 145(2), 592-603. 
Armitage, P., \& Berry, G. (1987). Comparison of several groups. In Statistical method in medical research, (2nd ed., pp. 186-213). Oxford: Blockwell Significant Publication.

Armstrong, D. (1998). Free radicals and antioxidant protocols, 108, 315-324.

Bancroft, J., Stevens, A., Turner, D., 1996. Theory and practice of histological techniques, fourth Edition. Churchil Livingstone, New York, London, San Francisco, Tokyo

Barsiene, J., Syvokiene, J., \& Bjornstad, A. (2006). Induction of micronuclei and other nuclear abnormalities in mussels exposed to bisphenol a, diallyl phthalate and tetrabromodiphenyl ether-47. Aquatic Toxicology, 78, 105-108.

Biedermann, S., Tschudin, P., \& Grob, K. (2010). Transfer of bisphenol a from thermal printer paper to the skin. Analytical and Bioanalytical Chemistry, 398, 571-576.

Bindhumol, V., Chitra, K. C., \& Mathur, P. P. (2003). Bisphenol a induces reactive oxygen species generation in the liver of male rats. Toxicology, 188, 117-124.

Bolognesi, C., Perrone, E., Roggieri, P., Pampanin, D. M., \& Sciutto, A. (2006). Assessment of micronuclei induction in peripheral erythrocytes of fish exposed to xenobiotics under controlled conditions. Aquatic Toxicology, 78, S93-S98.

Boshra, V., \& Moustafa, A. M. (2011). Effect of preischemic treatment with fenofibrate, a peroxisome proliferator-activated receptoralpha ligand, on hepatic ischemiareperfusion injury in rats. Journal of olecular Histology, 42, 113-122.

Calafat, A. M., Kuklenyik, Z., Reidy, J. A., Caudill, S. P., Ekong, J., \& Needham, L. L. (2005). Urinary concentrations of bisphenol a and 4-nonylphenol in a human reference population. Environmental Health Perspectives, 133, 391-395.

Chapin, R. E., Adams, J., Boekelheide, K., Gray Jr., L. E., Hayward, S. W., Lees, P. S., McIntyre, B.S., Portier, K. M., Schnorr, T. M., Selevan, S. G., Vandenbergh, J. G., Woskie, S. R. (2008). NTP-CERHR expert panel report on the reproductive and developmental toxicity of bisphenol a. Birth Defects Research. Part B, Developmental and Reproductive Toxicology, 83, 157-395.

Chitra, K. C., Latchoumycandane, C., \& Mathur, P. P. (2002). Effect of nonylphenol on the antioxidant system in epididymal sperm of rats. Archives of Toxicology, $76,545-551$.

Eddy, E. M. (2002). Male germ cell gene expression. Recent Progress in Hormone Research, 57, 103-128.

Eid, J. I., Eissa, S. M., \& EL-Ghor, A. A. (2015). Bisphenol a induces oxidative stress and DNA damage in hepatic tissue of female rat offspring. The Journal of Basic \& Applied Zoology, 71, 10-19.

Fenech, M. (2000). The in vitro micronucleus technique. Mutation Research, 455, 81-95.

Furuya, M., Adachi, K., Kuwahara, S., Ogawa, K., \& Tsukamoto, Y. (2006). Inhibition of male chick phenotypes and spermatogenesis by bisphenol-A. Life Sciences, 78, 1767-1776

Gray, L. E., Jr, Ostby, J., Furr, J., Wolf, C. J., Lambright, C., Parks L., Veeramachaneni, D. N., Wilson, V., Price, M., Hotchkiss, A.,Orlando, E. \& Guillette, L.2001. Effects of environmental antiandrogens on reproductive development in experimental animals. Human Reproduction Update 7,248-264.

Griveau, J. F., Dumont, E., Renard, P., Callegari, J. P., \& Le Lannou, D. (1995). Reactive oxygen species, lipid peroxidation and enzymatic defense systems in human spermatozoa. Journal of Reproduction and Fertility, 103, 17-26.

Halliwell, B. (1996). Antioxidants in human health and disease. Annual Review of Nutrition., 16, 33-50.

Hanioka, N., Jinno, H., Nishimura, T., \& Ando, M. (1998). Suppression of malespecific cytochrome P450 isoforms by bisphenol a in rat liver. Archives of Toxicology, 72, 387-394.

Hassan, A. H., Ismail, A. A., \& Khudir, A. N. (2013). Effects of pre-and postnatal exposure to Bisphenol-A on the reproductive efficacy in male albino rats. Journal of Kerbala University., 11(3), 1-15.

Hassan, Z. K., Elobeid, M. A., Virk, P., Omer, S. A., \& ElAmin, M. (2012). Bisphenol A induces hepatotoxicity through oxidative stress in rat model. Oxidative Medicine and Cellular Longevity, 194829, 24.

Hernandez-Rodriguez, G., Zumbado, M., Luzardo, O. P., Monterde, J. G., Blanco, A., \& Boada, L. D. (2007). Multigenerational study of the hepatic effects exerted by the consumption of nonylphenol- and 4-octylphenol-contaminated drinking water in Sprague-Dawley rats. Environmental Toxicology and Pharmacology, 23, 73-81.

Huang, Y.Q. , Wong, C. K., Zheng , J.S., Bouwman, H., Barra, R., Wahlstrom, B., Neretin, L., Wong, M.H., 2011. Bisphenol A (BPA) in China: a review of sources, environmental levels, and potential human health impacts. Environment International. vol. May 17,. In press.

Huc, L., Lemarie, A., Gueraud, F., \& Helies-Toussaint, C. (2012). Low concentrations of bisphenol a induce lipid accumulation mediated by the production of reactive oxygen species in the mitochondria of HepG2 cells. Toxicology In Vitro, 26, 709-717.

Hunt, P. A., Koehler, K. E., Susiarjo, M., Hodges, C. A., llagan, A., Voigt, R. C., Thomas, S., Thomas, B.F., Hassold, T. J. (2003). Bisphenol a exposure causes meiotic aneuploidy in the female mouse. Current Biology, 13, 546-553.

Hussein, R. M., \& Eid, J. I. (2013). Pathological mechanisms of liver injury caused by oral administration of bisphenol A. Life Science Journal., 10(1), 663-673.

Ikezuki, Y. , Tsutsumi, O., Takai , Y., Kamei, Y., Taketani, Y., 2002. Determination of bisphenol a concentrations in human biological fluids reveals significant early prenatal exposure. Human Reproduction: Oxford England. 17, 2839-2841

Jayashree, S., Indumathi, D., Akilavalli, N., Sathish, S., Selvaraj, J., \& Balasubramanian, K. (2013). Effect of Bisphenol-A on insulin signal transduction and glucose oxidation in liver of adult male albino rat. Environmental Toxicology and Pharmacology, 35, 300-310.

Johnson, G. E., \& Parry, E. M. (2008). Mechanistic investigations of low dose exposures to the genotoxic compounds bisphenol-a and rotenone. Mutation Research, 651, 56-63.

Kabuto, H., Hasuike, S., Minagawa, N., \& Shishibori, T. (2003). Effects of bisphenol a on the active oxygen species in mouse tissues. Environmental Research, 93, 31-35.

Kawai, K., Nozaki, T., Nishikata, H., Aou, S., Takii, M., \& Kubo, C. (2003). Aggressive behavior and serum testosterone concentration during the maturation process of male mice: the effects of fetal exposure to bisphenol A. Environmental Health Perspectives, 111, 175-178.

Kopf, M., Bachmann, M.F., Marsland, B.J. 2010. Averting inflammation by targeting the cytokine environment. Nature reviews. Drug Discovery 9, 703-718.

Korkmaz, A., Ahbab, M. A., Kolankaya, D., \& Barlas, N. (2010). Influence of vitamin C on bisphenol A, nonylphenol and octylphenol induced oxidative damages in liver of male rats. Food and Chemical Toxicology, 48, 2865-2871.

Kroemer, G., Galluzzi, L., \& Brenner, C. (2007). Mitochondrial membrane permeabilization in cell death. Physiological Reviews, 87, 99-163.

Kurosawa, T., Hiroi, H., Tsutsumi, O., Ishikawa, T., Osuga, Y., Fujiwara, T., Inoue, S., Muramatsu, M., Momoeda, M., Taketani, Y. (2002). The activity of bisphenol a depends on both the estrogen receptor subtype and the cell type. Endocrine Journal., 49, 465-471.

Livak, K. J., \& Schmittgen, T. D. (2001). Analysis of relative gene expression data using real-time quantitative PCR and the 22DDCT. Methods, 25, 402-408.

Lu, T., Finkel, T., 2008. Free radicals and senescence. Experimental Cell Research. Jan 26 Epub ahead of print.

Masuda, S., Terashima, Y., Sano, A., Kuruto, R., Sugiyama, Y., Shimoi, K., Tanji, K. Yoshioka, H., Terao, Y., Kinae, N. (2005). Changes in the mutagenic and estrogenic activities of bisphenol a upon treatment with nitrite. Mutation Research, 585, 137-146.

Meeker, J. D., Shelley, E., Thomas, L. T., Diane, L. W., Calafat, A. M., Trisini, A. T., Ye, X., Hauser, R. (2010). Semen quality and sperm DNA damage in relation to urinary bisphenol A among men from an infertility clinic. Reproductive Toxicology, 30, 532-539.

Mourad, I. M., \& Khadrawy, Y. A. (2012). The sensitivity of liver, kidney and testis of rats to oxidative stress induced by different doses of bisphenol $A$. International Journal of Life Science and Pharma Reviews, 2, 19-28.

MSDS 2004. Bisphenol A material safety DataSheet. In www.sigma-aldrich.com.

Mytilineou, C. (2002). Parkinsonism Relat. Disord., 8, 385-387.

Nakagawa, Y., \& Tayama, S. (2000). Metabolism and cytotoxicity of bisphenol a and other bisphenols in isolated rat hepatocytes. Archives of Toxicology, 74, 99-105.

Nakamura, D., Yanagiba, Y., Duan, Z., Ito, Y., Okamura, A., Asaeda, N., Tagawa, Y., Li, C., Taya, K., Zhang, S. Y., Naito, H., Ramdhan, D. H., Kamijima, M., Nakajima, T. (2010). Bisphenol a may cause testosterone reduction by adversely affecting both testis and pituitary systems similar to estradiol. Toxicology Letters, 194, 16-25.

Nakanishi, Y. (1995). Study on the mammalian spermatogenic pathway. Yakugaku Zasshi, 115, 420-430.

Nandi, D., Patra, R. C., \& Swarup, D. (2005). Effect of cysteine, methionine, ascorbic acid and thiamine on arsenic-induced oxidative stress and biochemical alterations in rats. Toxicology, 211, 226-235.

Parry, E. M., Parry, J. M., Corso, C., Doherty, A., Haddad, F., Hermine, T. F., Johnson, G., Kayani, M., Quick, E., Warr, T., Williamson, J. (2002). Detection and characterization of mechanisms of action of aneugenic chemicals. Mutagenesis, 17, 509-521.

Pfeiffer, E., Rosenberg, B., Deuschel, S., \& Metzler, M. (1997). Interference with microtubules and induction of micronuclei in vitro by various bisphenols. Mutation Research, 390, 21-31. 
Quick, E. L., Parry, E. M., \& Parry, J. M. (2008). Do oestrogens induce chromosome specific aneuploidy in vitro, similar to the pattern of aneuploidy seen in breast cancer. Mutation Research, 651, 46-55.

Rao, S. K. P., Rahiman, M. A., \& Koranne, S. P. (1983). Bovine albumin as a substitute for fetal calf serum in the micronucleus test, (p. 28). Madras: International Symposium on Recent Trends in Medical Genetics.

Richter, C. A., Birnabaum, L. S., Farabollini, F., Newbold, R. R., Rubin, B. S., Talsness, C. E., Vaderbergh, J. G., Walser-Kuntz, D. R., Vom Saal, F. S. (2007). In vivo effect of bisphenol A in laboratory rodent studies. Reproductive Toxicology, 24, 199-224.

Rosenblum, E. R., Gavaler, J. S., \& Van Thiel, D. H. (1989). Lipid peroxidation: a mechanism for alcohol-induced testicular injury. Free Radical Biology \& Medicine, 7(5), 569-577.

Roy, S., Kalita, C. J., \& Mazumdar, M. (2011). Histopathological effects of bisphenol A on liver of Heteropneustes Fossilis (Bloch). Int. Q. J.Environ. Sci. Ecoscan, 1, 187-190.

Sakaue, M., Ohsako, S., Ishimura, R., Kurosawa, S., Kurohmaru, M., Hayashi, Y., Aoki, Y., Yonemoto, J., Tohyama, C. (2001). Bisphenol-A affects spermatogenesis in the adult rat even at a low dose. Journal of Occupational Health, 43, 185-190.

Schonfelder, G., Wittfoht, W., Hopp, H., Tallness, C. E., Paul, M., \& Chahoud, I. (2002). Parent bisphenol A accumulation in the human maternal-fetalplacental unit. Environmental Health Perspectives, 110, 703-707.

Takahashi S., Chi X.J., Yamaguchi Y., Suzuki H., Sugaya S., Kita K. 2001. Mutagenicity of bisphenol A and its suppression by interferon-alpha in human RSa cells, Mutant Research. 490,199-207.

Tiwari, D., Kamble, J., Chilgunde, S., Patil, P., Maru, G., Kawle, D., Bhartiya, U., Joseph, L., Vanage, G. (2012). Clastogenic and mutagenic effects of bisphenol A: an endocrine disruptor. Mutant Research, 743, 83-90.

Tsutsui, T., Tamura, Y., Suzuki, A., Hirose, Y., Kobayashi, M., \& Nishimura, H. (2000). Mammalian cell transformation an aneuploidy induced by five bisphenols. International Journal of Cancer, 86, 151-154.

Vandenberg, L.N., Chahoud, I., Heindel, J.J., Padmanabhan, V., Paumgartten, F.J., Schoenfelder, G. 2010. Urinary, circulating, and tissue biomonitoring studies indicate widespread exposure to bisphenol A. Environmental Health Perspectives., 2010; 118: 1055-1070

Vanderhyden, B. (2002). Molecular basis of ovarian development and function. Frontiers in Bioscience, 7, 2006-2022.

Vaux, D. L. (2011). Apoptogenic factors released from mitochondria. Biochimica et Biophysica Acta, 1813, 546-550

Verma, R. J., \& Sangai, N. P. (2009). The ameliorative effect of black tea extract and quercetin on bisphenol A-induced cytotoxicity. Acta Poloniae Pharmaceutica, 66, 41-44.

Wu, J. B., Chuang, H. R., Yang, L. C., \& Lin, W. C. (2010). A standardized aqueous extract of Anoectochilus formosanus ameliorated thioacetamide-induced liver fibrosis in mice: Therole of Kupffer cells. Bioscience, Biotechnology, and Biochemistry, 74, 781-787.

Wu, M., Xu, H., Shen, Y., Qiu, W., \& Yang, M. (2011). Oxidative stress in zebrafish embryos induced by short-term exposure to bisphenol $\mathrm{A}$, nonylphenol, and their mixture. Environmental Toxicology and Chemistry, 30(10), 2335-2341.

Xia, W., Jiang, Y., Li, Y., Wan, Y., \& Liu, J. (2014). Early-life exposure to bisphenol a induces liver injury in rats involvement of mitochondria-mediated apoptosis. PLoS One, 9, e90443.

Yongvanit, P., Pinlaor, S., \& Bartsch, H. (2012). Oxidative and nitrative DNA damage: Key events in opisthorchiasis-induced carcinogenesis. Parasitology International, 61, 130-135.

Zimmermann, H. W., \& Tacke, F. (2011). Modification of chemokine pathways and immune cell infiltration as a novel therapeutic approach in liver inflammation and fibrosis. Inflammation \& Allergy Drug Targets, 10, 509-536.

\section{Submit your manuscript to a SpringerOpen ${ }^{\circ}$ journal and benefit from:}

- Convenient online submission

- Rigorous peer review

- Open access: articles freely available online

- High visibility within the field

- Retaining the copyright to your article

Submit your next manuscript at $\gg$ springeropen.com 